\title{
Recommendations for the treatment of epilepsy in adult and pediatric patients in Belgium: 2020 update
}

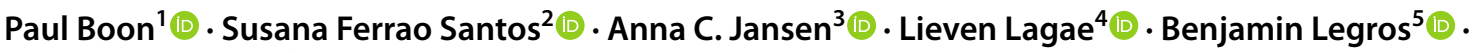 \\ Sarah Weckhuysen ${ }^{6,7}$ (1)
}

Received: 24 July 2020 / Accepted: 26 August 2020 / Published online: 13 October 2020

(c) The Author(s) 2020

\begin{abstract}
To guide health care professionals in Belgium in selecting the appropriate antiepileptic drugs (AEDs) for their epilepsy patients, a group of Belgian epilepsy experts developed recommendations for AED treatment in adults and children (initial recommendations in 2008, updated in 2012). As new drugs have become available, others have been withdrawn, new indications have been approved and recommendations for pregnant women have changed, a new update was pertinent. A group of Belgian epilepsy experts (partly overlapping with the group in charge of the 2008/2012 recommendations) evaluated the most recent international guidelines and relevant literature for their applicability to the Belgian situation (registration status, reimbursement, clinical practice) and updated the recommendations for initial monotherapy in adults and children and add-on treatment in adults. Recommendations for add-on treatment in children were also included (not covered in the 2008/2012 publications). Like the 2008/2012 publications, the current update also covers other important aspects related to the management of epilepsy, including the importance of early referral in drug-resistant epilepsy, pharmacokinetic properties and tolerability of AEDs, comorbidities, specific considerations in elderly and pregnant patients, generic substitution and the rapidly evolving field of precision medicine.
\end{abstract}

Keywords Epilepsy $\cdot$ Seizures $\cdot$ Antiepileptic drugs $\cdot$ Recommendations $\cdot$ Monotherapy $\cdot$ Add-on therapy

\section{Introduction}

Epilepsy is one of the most common neurological diseases, affecting approximately 50,000,000 people worldwide [1]. In Belgium, an estimated 100,000 people are living with epilepsy [2]. The disease is defined by the occurrence of at least two unprovoked seizures more than $24 \mathrm{~h}$ apart or one unprovoked seizure and a high risk of recurrence (at least $60 \%$ ), or by the diagnosis of an epilepsy syndrome [3]. In 2017, the International League Against Epilepsy (ILAE) updated their classification of seizure types, using seizure onset as their basis. They distinguish focal-onset seizures (originating in

Epidyolex/Epidiolex is a trademark of GW Pharma Limited.

Susana Ferrao Santos, Anna C. Jansen, Lieven Lagae, Benjamin Legros and Sarah Weckhuysen have contributed equally to the article.

Paul Boon

Paul.Boon@UZGent.be

Extended author information available on the last page of the article one hemisphere, formerly called partial seizures), generalized-onset seizures (originating in both hemispheres, e.g., absences, generalized tonic-clonic, atonic and myoclonic seizures) and seizures of unknown onset [4]. Seizures that start focally and spread to bilateral tonic-clonic movements (previously called secondarily generalized tonic-clonic seizures) are referred to as focal-to-bilateral tonic-clonic seizures [4].

Once a diagnosis of epilepsy is confirmed, most patients are treated with antiepileptic drugs (AEDs). Currently, more than 20 different AEDs are registered in Belgium [5]. While this large number allows tailoring treatment to individual patients' needs, it makes selection of the most suitable compound complex. The choice of an AED depends on the patient's seizure type, age, sex, childbearing potential, comorbidities and concomitant medications, and the drug's adverse effect and interaction profiles (Fig. 1). To guide health care professionals in Belgium in making this choice, a group of experts developed recommendations for the management of epilepsy in adults and children in general neurological practice in Belgium in 2008 [6] and updated these in 


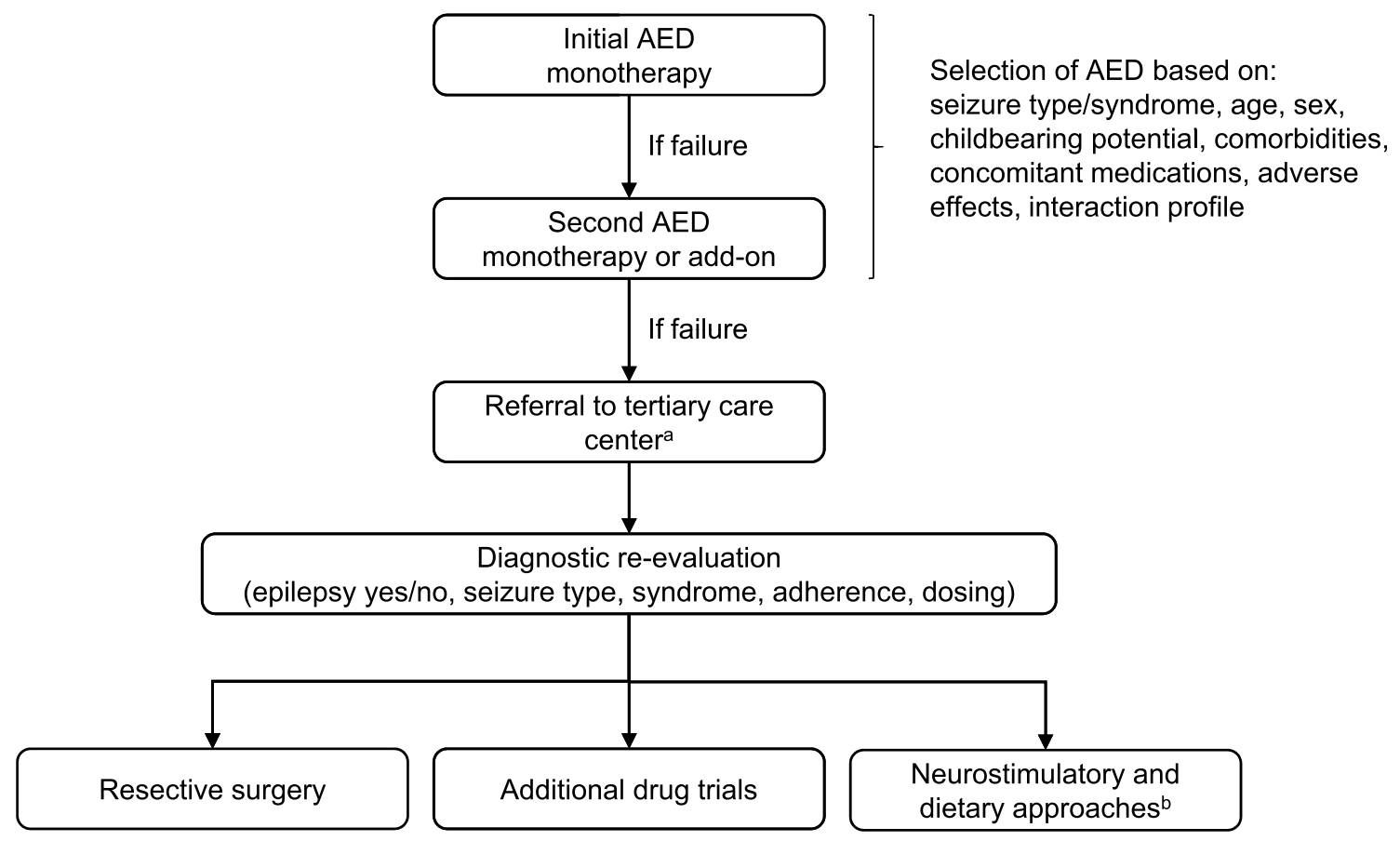

Fig. 1 Epilepsy treatment pathway. AED, antiepileptic drug. ${ }^{\text {aPrompt }}$ referral of patients with drug-resistant epilepsy or certain complex epilepsy syndromes is crucial to improve a patient's chances to achieve seizure control and avoid life-long sequelae. ${ }^{\text {b Neurostimula- }}$ tory approaches include vagus nerve and deep brain stimulation; dietary approaches include ketogenic and modified Atkins diet
2012 [7]. Since then, new indications of previously available AEDs have been approved (e.g., monotherapy and changes in the lower age limit for lacosamide $[8,9]$ ), new AEDs have become available (e.g., perampanel and brivaracetam $[10,11])$ and others have disappeared from the market (e.g., pheneturide and retigabine $[12,13])$. Changes in clinical practice are also warranted for certain subpopulations, especially pregnant women. A new update of the recommendations therefore seemed pertinent.

\section{Methodology}

The initial recommendations for the management of epilepsy in general neurological practice in Belgium [6] and the updated recommendations [7] were based on guidelines by the ILAE [14], the American Academy of Neurology (AAN $[15,16])$, the Scottish Intercollegiate Guidelines Network (SIGN [17]) and the United Kingdom National Institute for Health and Care Excellence (NICE [18]), and relevant articles on controlled clinical trials published after the cut-off dates used in these guidelines. This resulted in recommendations for initial monotherapy in adults and children and for add-on treatment in adults [6, 7].

In October 2019, a group of Belgian epilepsy experts (partly overlapping with the group in charge of the 2008/2012 recommendations) convened to discuss the strategy to update the current recommendations. Following this first meeting, the ILAE, AAN, SIGN and NICE websites were searched for updates to their guidelines. The AAN published updated guidelines for the treatment of new-onset and drug-resistant epilepsy in 2018 [19, 20], SIGN published updated guidelines for the management of epilepsy in adults in 2015 with revisions in 2018 [21] and NICE published updated guidelines for the management of epilepsy in children and adults in 2012 with a last revision in 2020 [22]. No updates to the ILAE guidelines (encompassing the general adult or pediatric patient population) were found but an updated evidence review of AED efficacy and effectiveness as initial monotherapy was published in 2013 [23], and a report on the management of epilepsy during pregnancy in 2019 [24]. As the last fully updated guidelines (AAN) were based on a systematic literature search up to November 2015, the information extracted from the different guidelines was supplemented with information from (systematic) reviews and/or meta-analyses on AED treatment (comparing multiple AEDs) published between January 2016 and February 2020, retrieved by searching PubMed and the Cochrane Library.

The experts evaluated the updated AAN, SIGN and NICE guidelines, the ILAE evidence review and the relevant published articles for their applicability to the Belgian situation (registration status, reimbursement, clinical practice) and prepared an update of the recommendations for initial 
monotherapy in adults and children and add-on treatment in adults. In addition, recommendations for add-on treatment in children were included, which were not covered in the 2008/2012 publications.

The following criteria were used to prepare the treatment recommendations in this update:

1. The AED is registered and reimbursed in Belgium [5, 25]. Remarks are included for drugs that were proven to be effective for a certain indication but are currently not registered or reimbursed for that indication in Belgium.

2. The AEDs with the highest level of evidence for efficacy across the different guidelines or evidence reviews are recommended as first choice. As the different guidelines do not all use the same method to rate the evidence in the studies they reviewed, no levels of evidence for efficacy are stated in the current recommendations.

3. In the rare cases where the level of evidence for different AEDs was the same or where evidence was limited, recommendations were based on a consensus among the authors.

The same definitions as in the 2008/2012 recommendations were used $[6,7]$ :

- First choice: First treatment choice in a patient without any specific factors precluding the use of this AED (e.g., comorbidity, concomitant medication).

- Alternative first choice: AED recommended when certain patient-related factors (e.g., comorbidity, concomitant medication) or AED-related factors (e.g., interaction potential, contraindications, adverse effect profile) preclude the use of the first-choice AED.

Wherever possible, the newly developed ILAE 2017 classification of seizure types was used [4].

\section{Recommendations for treatment}

\section{Initial monotherapy in adults and children}

\section{Focal-onset seizures}

Registered and reimbursed treatment options for monotherapy of focal-onset seizures (including focal-to-bilateral seizures) in adults and children in Belgium are carbamazepine, lamotrigine (age $\geq 12$ years), levetiracetam ( $\geq 16$ years), oxcarbazepine ( $\geq 6$ years), phenobarbital, phenytoin, primidone, topiramate ( $\geq 6$ years) and valproate (Table 1 ). Since the 2012 publication, pheneturide was withdrawn [12] and lacosamide was approved for monotherapy of focal-onset seizures $(\geq 4$ years $[8,9])$ but is not reimbursed for this indication. Similarly, gabapentin is approved but not reimbursed for monotherapy of focal-onset seizures ( $\geq 12$ years) (Table 1).

Of these options, carbamazepine, lamotrigine, levetiracetam and oxcarbazepine are recommended as first choice, while topiramate and valproate are suitable alternative first choices (except for valproate in women/girls of childbearing potential) (Table 2) [20-23, 26, 27]. Since approximately $50 \%$ of patients respond to the first monotherapy [28], it should be appropriately chosen including tolerability profile, risk for future pregnancies and drug interactions. Hence, phenytoin and phenobarbital should not be first choices, despite being approved and reimbursed (author consensus). Evidence from randomized trials is more limited in children [29] and the aforementioned age restrictions should be taken into account in the pediatric recommendations (e.g., levetiracetam is not licensed as monotherapy in children $<16$ years). Compared to carbamazepine, which has been used for over 50 years, several of the newer AEDs (e.g., lamotrigine, levetiracetam and oxcarbazepine) have a more favorable pharmacokinetic profile and lamotrigine is better tolerated [30].

\section{Generalized-onset seizures}

Generalized-onset seizures include motor seizures (e.g., tonic-clonic, myoclonic, atonic) and non-motor or absence seizures [4]. Not all AEDs indicated for generalized-onset seizures cover all these seizure types. Registered and reimbursed treatment options for monotherapy of generalizedonset tonic-clonic seizures in adults and children in Belgium are carbamazepine, lamotrigine (age $\geq 12$ years), phenobarbital, phenytoin, primidone, topiramate ( $\geq 6$ years) and valproate (Table 1). Since the 2012 publication, no new AEDs have become available as monotherapy for this indication in Belgium. Ethosuximide ( $\geq 3$ years), lamotrigine ( $\geq 2$ years) and valproate are registered and reimbursed as monotherapy for absence seizures (Table 1).

Valproate, phenobarbital and primidone are available for the treatment of myoclonic and/or other generalized seizure types (e.g., atonic).

For generalized-onset tonic-clonic seizures, valproate is recommended as first choice (except in women/girls of childbearing potential); lamotrigine and topiramate are valuable alternatives, however, lamotrigine can aggravate myoclonic seizures (e.g., in patients with Juvenile Myoclonic Epilepsy [JME]) (Table 2) [21-23, 27, 31, 32]. Levetiracetam is effective as monotherapy for generalizedonset tonic-clonic seizures $[27,31,32]$ but is currently not reimbursed for this seizure type in Belgium. Carbamazepine can also be considered as monotherapy for generalized-onset tonic-clonic seizures but is not effective against 


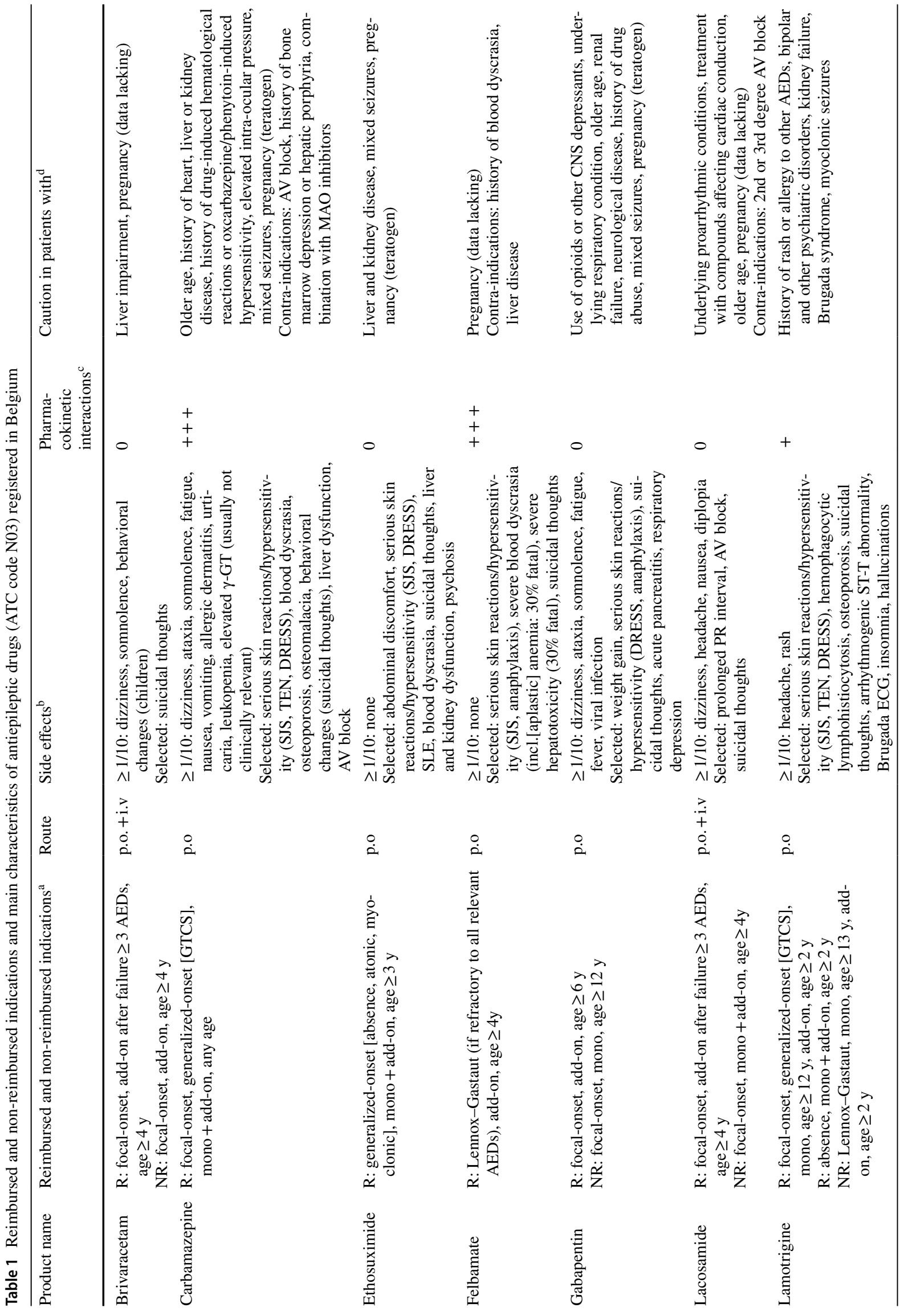




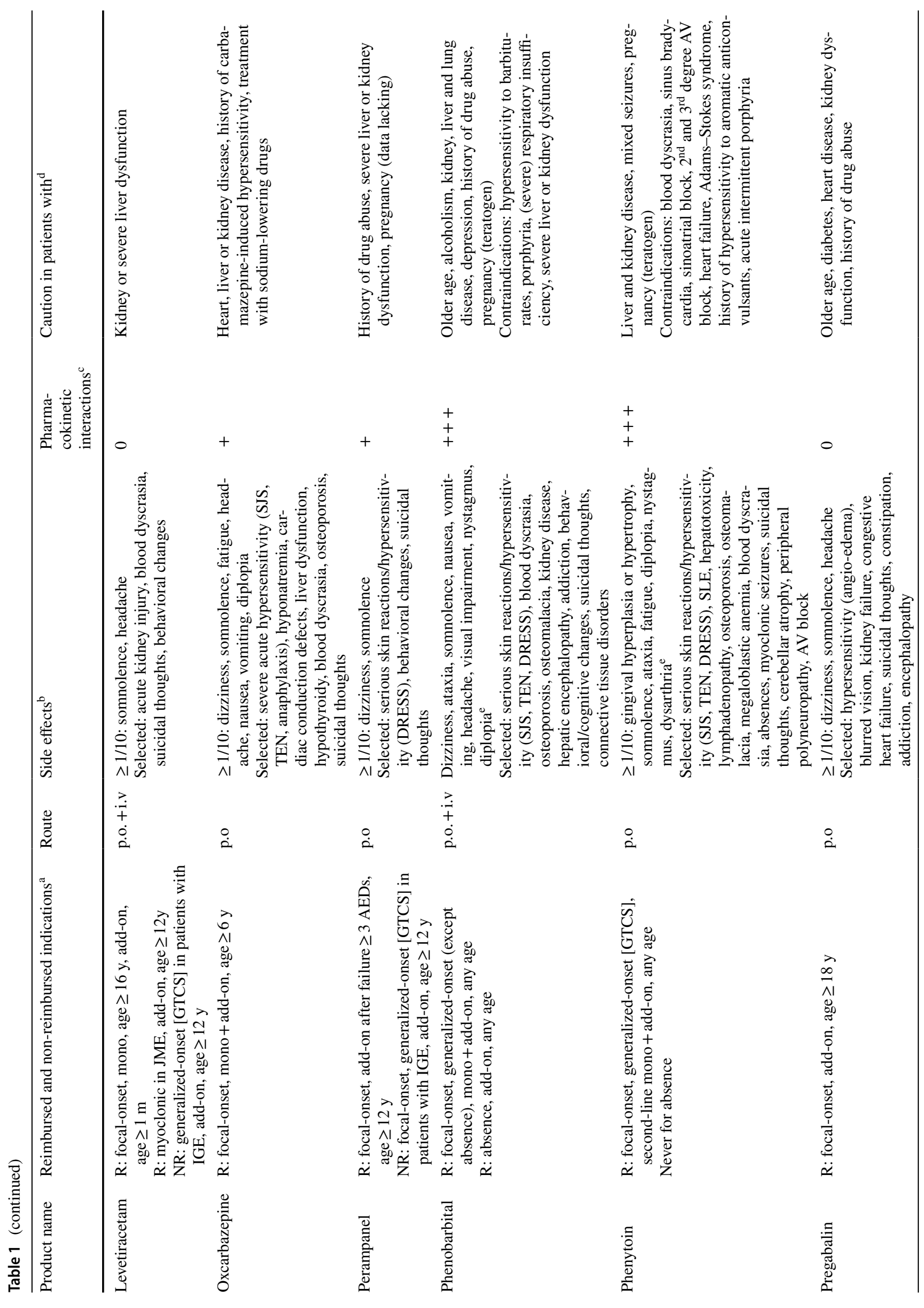




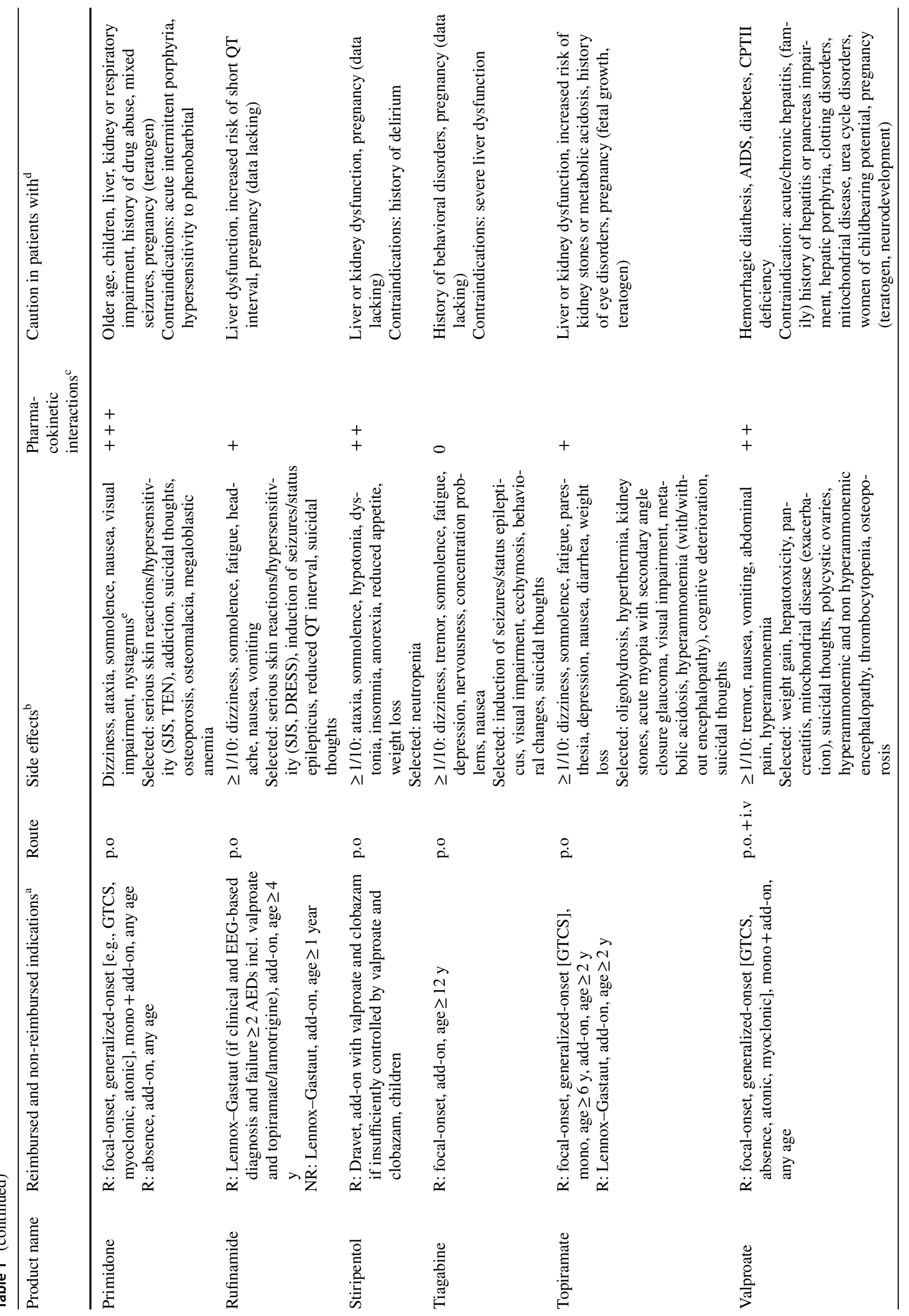




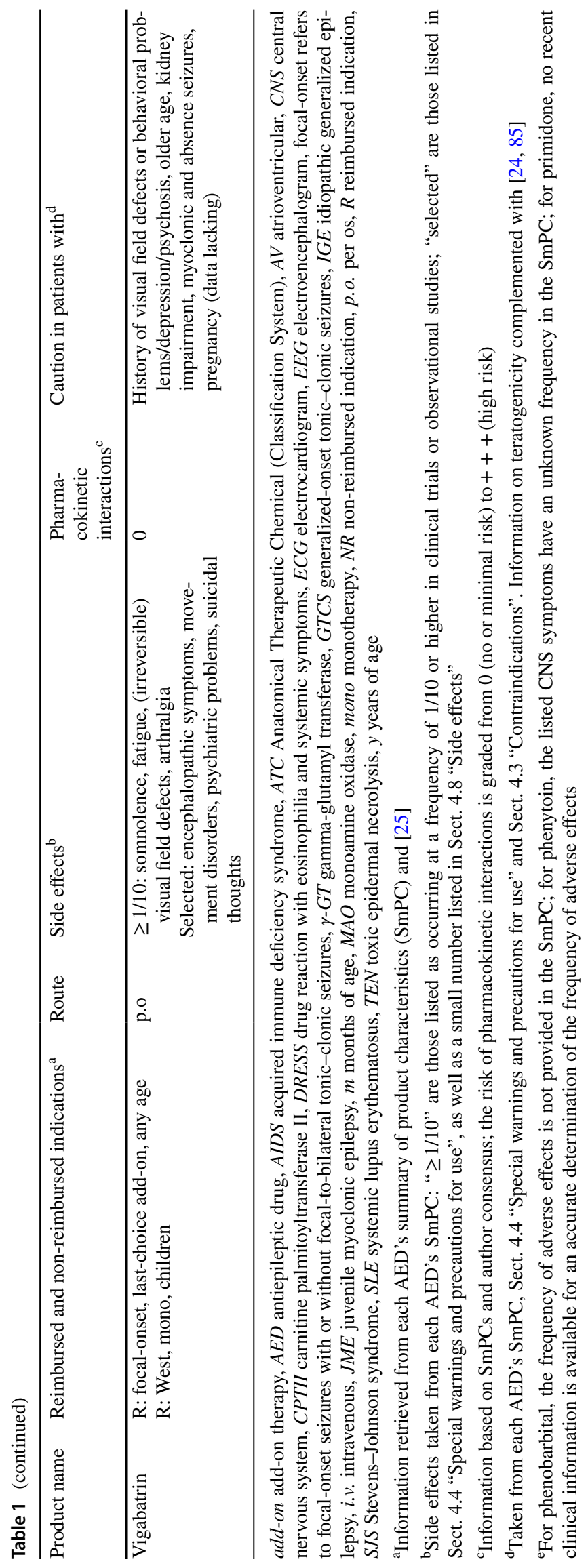


Table 2 Recommendations for initial monotherapy and add-on therapy for seizures in adults and children

\begin{tabular}{|c|c|c|c|c|}
\hline Seizure type & $\begin{array}{l}\text { Monotherapy } \\
\text { First choice }\end{array}$ & $\begin{array}{l}\text { Monotherapy } \\
\text { Alternative first choice }\end{array}$ & Add-on therapy & Remarks \\
\hline $\begin{array}{l}\text { Focal-onset seizures } \\
\text { (including focal-to- } \\
\text { bilateral tonic-clonic } \\
\text { seizures) }\end{array}$ & $\begin{array}{l}\text { Carbamazepine } \\
\text { Lamotrigine }(\geq 12 \mathrm{y}) \\
\text { Levetiracetam }(\geq 16 \mathrm{y}) \\
\text { Oxcarbazepine }(\geq 6 \mathrm{y})\end{array}$ & $\begin{array}{l}\text { Topiramate }(\geq 6 \mathrm{y}) \\
\text { Valproate }\end{array}$ & $\begin{array}{l}\text { Brivaracetam }(\geq 4 \mathrm{y}) \\
\text { Carbamazepine } \\
\text { Gabapentin }(\geq 6 \mathrm{y}) \\
\text { Lacosamide }(\geq 4 \mathrm{y}) \\
\text { Lamotrigine }(\geq 2 \mathrm{y}) \\
\text { Levetiracetam }(\geq 1 \mathrm{~m}) \\
\text { Oxcarbazepine }(\geq 6 \mathrm{y}) \\
\text { Perampanel }(\geq 12 \mathrm{y}) \\
\text { Pregabalin }(\geq 18 \mathrm{y}) \\
\text { Tiagabine }(\geq 12 \mathrm{y}) \\
\text { Topiramate }(\geq 2 \mathrm{y}) \\
\text { Valproate }\end{array}$ & $\begin{array}{l}\text { Lamotrigine and levetiracetam are pre- } \\
\text { ferred over carbamazepine in older } \\
\text { patients due to their better tolerability } \\
\text { and lower risk of drug-drug interac- } \\
\text { tions [ } 80,81] \\
\text { Tiagabine is rarely used; gabapentin } \\
\text { and pregabalin are infrequently used } \\
\text { Brivaracetam, lacosamide and per- } \\
\text { ampanel are only reimbursed after } \\
\text { failure of at least three AEDs } \\
\text { Clobazam can be considered as add-on } \\
\text { treatment (but is not reimbursed for } \\
\text { epilepsy) [19, 22] } \\
\text { Vigabatrin can also be used as add-on } \\
\text { treatment but only as last choice } \\
\text { because of its unfavorable safety } \\
\text { profile } \\
\text { Avoid valproate in pregnant women/ } \\
\text { women of childbearing potential }\end{array}$ \\
\hline $\begin{array}{l}\text { Generalized-onset tonic- } \\
\text { clonic seizures, (tonic } \\
\text { and atonic seizures) }\end{array}$ & Valproate & $\begin{array}{l}\text { Carbamazepine } \\
\text { Lamotrigine }(\geq 12 \mathrm{y}) \\
\text { Topiramate }(\geq 6 \mathrm{y})\end{array}$ & $\begin{array}{l}\text { Carbamazepine } \\
\text { Lamotrigine }(\geq 2 \mathrm{y}) \\
\text { Levetiracetam }(\mathrm{NR} ; \geq 12 \mathrm{y}) \\
\text { Topiramate }(\geq 2 \mathrm{y}) \\
\text { Valproate }\end{array}$ & $\begin{array}{l}\text { Carbamazepine can be considered (for } \\
\text { tonic-clonic seizures) but should be } \\
\text { avoided if absence or myoclonic sei- } \\
\text { zures are present or JME is suspected } \\
{[22,23]} \\
\text { Lamotrigine can aggravate myoclonic } \\
\text { seizures [22] } \\
\text { Levetiracetam is also effective as } \\
\text { monotherapy for generalized-onset } \\
\text { seizures [27, } 31,32] \text { but is currently } \\
\text { only licensed as add-on for this } \\
\text { seizure type } \\
\text { Clobazam could be considered as add- } \\
\text { on treatment (not reimbursed) [22] } \\
\text { Avoid valproate in pregnant women/ } \\
\text { women of childbearing potential }\end{array}$ \\
\hline Absence seizures & $\begin{array}{l}\text { Ethosuximide }(\geq 3 y) \\
\text { Valproate }\end{array}$ & Lamotrigine $(\geq 2 \mathrm{y})$ & $\begin{array}{l}\text { Ethosuximide }(\geq 3 \mathrm{y}) \\
\text { Lamotrigine }(\geq 2 \mathrm{y}) \\
\text { Valproate }\end{array}$ & $\begin{array}{l}\text { Carbamazepine, gabapentin, oxcar- } \\
\text { bazepine, phenobarbital, phenytoin, } \\
\text { pregabalin, tiagabine and vigabatrin } \\
\text { may aggravate absence seizures [22, } \\
23 \text { ] } \\
\text { Clobazam and clonazepam could be } \\
\text { considered as add-on treatment (not } \\
\text { reimbursed) [22] } \\
\text { Avoid valproate in pregnant women/ } \\
\text { women of childbearing potential }\end{array}$ \\
\hline Myoclonic seizures & Valproate & & $\begin{array}{l}\text { Levetiracetam ( } \geq 12 \mathrm{y} \text {; in JME) } \\
\text { Valproate }\end{array}$ & $\begin{array}{l}\text { Carbamazepine, gabapentin, lamo- } \\
\text { trigine, oxcarbazepine, phenytoin, } \\
\text { pregabalin, tiagabine and vigabatrin } \\
\text { may aggravate myoclonic seizures } \\
{[22,23]} \\
\text { Clobazam and clonazepam could be } \\
\text { considered as add-on treatment (not } \\
\text { reimbursed) [22] } \\
\text { Avoid valproate in pregnant women/ } \\
\text { women of childbearing potential }\end{array}$ \\
\hline
\end{tabular}

First choice refers to first treatment choice in a patient without any specific factors precluding the use of this antiepileptic drug (AED). Alternative first choice refers to AEDs recommended when certain patient- or AED-related factors preclude the use of the first-choice AED

The efficacy of older AEDs in add-on treatment is considered to be established during long-term clinical experience

$A E D$ antiepileptic drug, $J M E$ juvenile myoclonic epilepsy, $m$ month of age, $N R$ AED not reimbursed for the specified treatment type/indication, $y$ years of age 
other generalized-onset seizure types and can aggravate absences, myoclonic and tonic/atonic seizures [22, 23].

For absence seizures, ethosuximide and valproate are recommended as first choice (except for valproate in women/girls of childbearing potential) and lamotrigine as alternative first choice (Table 2) [20-23, 29, 31, 33]. For myoclonic and tonic/atonic seizures, valproate is recommended as first choice (except in women of childbearing potential) [22, 34]. Levetiracetam could be considered as alternative for myoclonic seizures [22, 34], although it is not registered for monotherapy for this seizure type (Table 2).

Notably, carbamazepine, gabapentin, oxcarbazepine, phenobarbital, phenytoin, pregabalin, tiagabine and vigabatrin may trigger or exacerbate myoclonic and/or absence seizures (Table 2) [22, 23].

\section{Seizures of unknown onset}

If the seizure type has not been established before starting AED treatment, a broad-spectrum AED (effective against the most common seizure types, such as valproate, lamotrigine, levetiracetam or topiramate) can be used (author consensus).

\section{Add-on treatment in adults and children}

If the AED chosen for initial monotherapy is ineffective in controlling seizures, a second AED is typically selected for either substitution monotherapy (preferred option) or add-on therapy (Fig. 1) [21, 22, 35]. Failure of a second AED may require additional trials of various combination therapies $[21,22,35]$. The choice of add-on AEDs depends on the same compound- and patient-related factors as those impacting the choice of the initial AED, and on the potential for interactions between the compounds. An increasing number of new AEDs, with different mechanisms of action, better pharmacokinetic profiles and better tolerability compared to the older AEDs have been licensed for add-on therapy in the last decades [36, 37]. "Rational polytherapy" relies on combining AEDs with complementary mechanisms of action that may work synergistically to maximize efficacy and minimize toxicity. Clinical trials and observational studies have shown that combinations of drugs with the same mechanism of action (e.g., sodium channel blockers) are typically associated with higher rates of adverse events and treatment discontinuation [35, 38]. Clinical studies have shown synergistic interactions in terms of efficacy for the combination of valproate and lamotrigine, while for other combinations clinical evidence is limited $[35,38]$. Therefore, the choice of AEDs in add-on therapy is still made on a case-by-case basis.

\section{Focal-onset seizures}

Registered and reimbursed AEDs for add-on treatment of focal-onset seizures in adults and children in Belgium are brivaracetam (age $\geq 4$ years), carbamazepine, gabapentin ( $\geq 6$ years), lacosamide ( $\geq 4$ years), lamotrigine ( $\geq 2$ years), levetiracetam ( $\geq 1$ month), oxcarbazepine ( $\geq 6$ years), perampanel ( $\geq 12$ years), phenobarbital, phenytoin, pregabalin ( $\geq 18$ years), primidone, tiagabine ( $\geq 12$ years), topiramate ( $\geq 2$ years), valproate and vigabatrin (last choice) (Table 1).

Changes in registration or reimbursement status of drugs used as add-on therapy for focal-onset seizures after the 2012 recommendations include the registration of brivaracetam and perampanel $[10,11]$, an extension of the lower age limit for lacosamide (from 16 to 4 years [8]) and the withdrawal of pheneturide and retigabine $[12,13]$.

AEDs recommended for add-on therapy of focal-onset seizures are brivaracetam, carbamazepine, gabapentin, lacosamide, lamotrigine, levetiracetam, oxcarbazepine, perampanel, pregabalin (adults only), tiagabine, topiramate and valproate (except for women/girls of childbearing potential for the latter) (Table 2) [19, 21, 22, 29, 39-42]. The benzodiazepine clobazam can also be considered in patients 6 years or older (but is not reimbursed for epilepsy treatment) [19, 22]. Brivaracetam, lacosamide and perampanel are only reimbursed after failure of at least three AEDs.

\section{Generalized-onset seizures}

Registered and reimbursed AEDs for add-on treatment of generalized-onset seizures in adults and children in Belgium did not change since the 2012 recommendations; reimbursed compounds are carbamazepine, ethosuximide ( $\geq 3$ years), lamotrigine ( $\geq 2$ years), levetiracetam (for JME, $\geq 12$ years), phenobarbital, phenytoin, primidone, topiramate ( $\geq 2$ years) and valproate (Table 1). In addition, levetiracetam and perampanel are registered but not reimbursed for add-on treatment of generalized-onset tonic-clonic seizures in individuals $\geq 12$ years.

Lamotrigine, topiramate and valproate are recommended as add-on treatment for generalized-onset tonic-clonic seizures in adults and children (taking into account the aforementioned age restrictions); levetiracetam and clobazam are also options (but are not reimbursed for this indication) (Table 2) $[19,21,22]$. Carbamazepine can be considered for generalized-onset tonic-clonic seizures (but should be avoided with other generalized seizure types). 
Recommendations for other generalized-onset seizure types are summarized in Table 2.

\section{Childhood epilepsy syndromes}

Table 3 summarizes treatment options in selected epilepsy syndromes in children: simple febrile seizures [43, 44], childhood absence epilepsy [33, 45], childhood epilepsy with centro-temporal spikes [22, 23, 43], electrical status epilepticus during sleep [46], West syndrome [22, 43, 44, 47, 48], Dravet syndrome [49], Lennox-Gastaut syndrome [50] and neonatal-onset epilepsies related to pathogenic variants in potassium and sodium channel genes $K C N Q 2$, SCN2A, SCN8A [51, 52]. For most of these syndromes, referral to a tertiary pediatric epilepsy specialist is recommended.

\section{Specific considerations}

\section{Drug-resistant epilepsy and the importance of early referral}

Around $30 \%$ of patients are refractory to AED treatment [53-55]. The ILAE's consensus definition of drug-resistant (or refractory) epilepsy is "failure of adequate trials of two tolerated and appropriately chosen and used AED schedules (whether as monotherapies or in combination) to achieve sustained seizure freedom" [56]. ILAE's consensus definition may help non-specialists recognize drug-resistant patients and ensure their prompt referral to tertiary care centers for expert evaluation and/or surgery (Fig. 1) [56]. Early referral of patients with drug-resistant epilepsy or with complex epilepsy syndromes (e.g., epileptic spasms [West syndrome], Dravet syndrome, continuous spikes and waves during slow sleep, tuberous sclerosis complex) is paramount to improve patients' chances to achieve seizure control and avoid impairment of neurological and cognitive development in children, irreversible psychological and social problems,

Table 3 Childhood epilepsy syndromes

\begin{tabular}{|c|c|c|c|}
\hline Syndrome & First line & Second line & Avoid \\
\hline Simple febrile seizures $[43,44]$ & None & $\begin{array}{l}\text { Valproate } \\
\text { Levetiracetam }\end{array}$ & \\
\hline Childhood absence epilepsy $[33,45]$ & Ethosuximide & $\begin{array}{l}\text { Valproate } \\
\text { (Lamotrigine) }\end{array}$ & $\begin{array}{l}\text { Carbamazepine, gabapentin, oxcarbazepine, } \\
\text { phenobarbital, phenytoin, tiagabine and } \\
\text { vigabatrin }[22,23]\end{array}$ \\
\hline $\begin{array}{l}\text { Childhood epilepsy with centro-temporal } \\
\text { spikes (Rolandic epilepsy) }[22,23,43]\end{array}$ & $\begin{array}{l}\text { Valproate } \\
\text { Levetiracetam } \\
\text { Sulthiame }^{\mathrm{a}}\end{array}$ & Carbamazepine & \\
\hline $\begin{array}{l}\text { Continuous spikes and waves during slow } \\
\text { sleep (CSWS)/Electrical status epilepti- } \\
\text { cus during sleep (ESES) [46] }\end{array}$ & $\begin{array}{l}\text { Levetiracetam } \\
\text { Steroids } \\
\text { Clobazam }\end{array}$ & & Carbamazepine, oxcarbazepine [22] \\
\hline $\begin{array}{l}\text { West syndrome (infantile spasms) [22, } 43 \text {, } \\
44,47,48]\end{array}$ & $\mathrm{ACTH} /$ prednisolone + vigabatrin & $\begin{array}{l}\text { Topiramate } \\
\text { Benzodiazepines } \\
\text { Valproate }\end{array}$ & \\
\hline Dravet syndrome [49] & Valproate + stiripentol + clobazam & $\begin{array}{l}\text { Topiramate } \\
\text { Cannabidiol }^{\mathrm{b}} \\
\text { Fenfluramine }^{\mathrm{c}} \\
\text { Ketogenic diet }\end{array}$ & $\begin{array}{l}\text { Sodium channel blockers (e.g., carbamaz- } \\
\text { epine) }\end{array}$ \\
\hline Lennox-Gastaut syndrome [50] & $\begin{array}{l}\text { Valproate } \\
\text { Rufinamide (add-on) } \\
\text { Clobazam }\end{array}$ & $\begin{array}{l}\text { Cannabidiol }{ }^{\mathrm{b}} \\
\text { Ketogenic diet }^{2}\end{array}$ & $\begin{array}{l}\text { Carbamazepine, oxcarbazepine, phenytoin, } \\
\text { tiagabine }\end{array}$ \\
\hline $\begin{array}{l}K C N Q 2, S C N 2 A, S C N 8 A \text {-related neonatal- } \\
\text { onset epilepsies }^{\mathrm{d}}[51,52]\end{array}$ & Carbamazepine & Phenytoin & \\
\hline
\end{tabular}

Recommendations are based on author consensus

${ }^{a}$ Sulthiame is registered and reimbursed for some epilepsy indications in Belgium but is not available on the Belgian market and has to be ordered from abroad

${ }^{\mathrm{b}}$ Cannabidiol is currently only available as non-reimbursed magistral preparation in Belgium

${ }^{c}$ Fenfluramine is not yet registered in Europe

${ }^{\mathrm{d}}$ Choice of treatment depends on the nature of the mutation (gain-of-function versus loss-of-function) 
life-long disability and premature death $[57,58]$. A recent systematic review showed that a shorter duration of epilepsy was significantly associated with a better seizure outcome after resective epilepsy surgery [59]. Aside from surgery, epilepsy centers can offer specialized diagnostic and therapeutic approaches that may identify the underlying cause of apparent or real drug resistance (e.g., non-adherence to medication, misdiagnosis, inadequate dosing, life style factors) and lead to seizure freedom in patients initially considered drug resistant (Fig. 1) [57, 58].

To treat drug-resistant epilepsy, non-AED treatment options can also be considered, including neurostimulatory approaches (e.g., vagus nerve stimulation [VNS] or deep brain stimulation [DBS]), ketogenic or modified Atkins diet and various complementary and behavioral approaches (Fig. 1) [21, 22, 53, 57, 58]. VNS can be considered in patients who are ineligible for resective surgery or for whom surgery failed. It has been shown to reduce seizure frequency in adults and children, and has shown mild and mostly temporary stimulation-related side effects that are different from common side effects of AEDs [60, 61]. DBS of the anterior nucleus of the thalamus (ANT-DBS) is an alternative neurostimulation modality that has shown long-term efficacy in drug-resistant patients [60, 62]. ANT-DBS has been shown to be well tolerated; most complications are related to the implantation technique. In patients with cognitive decline and mood disorders, caution is warranted [60, 62].

The ketogenic diet is a valid treatment option in children and adults with refractory epilepsy [61, 63]. It should be offered not as a last treatment option but earlier in the treatment flow chart. In some conditions, such as glucose transporter 1 (GLUT1) deficiency, and in some mitochondrial disorders, it is first-line treatment $[61,63]$. The ketogenic diet is also increasingly being used in refractory status epilepticus treatment and in some severe inflammatory epilepsies (e.g., new-onset refractory status epilepticus [NORSE]) [63]. In addition, immunotherapy has shown promise as adjunctive treatment in rare cases of autoimmune epilepsy, especially cases of NORSE. In particular, patients with febrile infection-related epilepsy syndrome (FIRES) benefit from targeted immunotherapy with anakinra (an interleukin-1 receptor antagonist) after failure of standard immune therapy such as steroids or intravenous immunoglobulins [64-66].

Cannabidiol has shown efficacy comparable to other AEDs, but only in children with drug-resistant Dravet or Lennox-Gastaut syndrome [67]. Pharmacies in Belgium are now allowed to prepare and dispense medicinal products containing cannabidiol using a magistral formula [68]. In September 2019, one commercial cannabidiolcontaining drug (Epidyolex, GW Pharma [International] B.V.) was approved by the European Medicines Agency as add-on therapy of seizures associated with Dravet or
Lennox-Gastaut syndrome, in conjunction with clobazam, in children $\geq 2$ years old [69]. This drug is not yet available in Belgium and magistral preparations are not reimbursed.

\section{Pharmacokinetic properties and pharmacokinetic interaction profile}

Given that many epilepsy patients require life-long treatment, take more than one AED and may take contraceptives or other drugs for diseases related or unrelated to epilepsy, it is important to minimize the risk of pharmacokinetic interactions when selecting AEDs. Pharmacokinetic interactions may alter plasma concentrations of AEDs and other drugs by affecting absorption, transport, distribution (plasma protein binding), metabolism and/or renal elimination [70-72]. This may result in reduced efficacy or tolerability.

Several newer AEDs (particularly brivaracetam, gabapentin, lacosamide and levetiracetam, Table 1) have a lower propensity of interactions because they do not induce or inhibit liver enzymes. The older AEDs, particularly hepatic enzyme inducers (e.g., carbamazepine, phenobarbital, phenytoin and primidone) and inhibitors (e.g., valproate) have a higher propensity for pharmacokinetic interactions (Table 1) [70-72].

\section{Tolerability}

Since efficacy of the newer generation AEDs has not improved substantially compared to the older AEDs, tolerability and safety are often the driving factors in selecting the optimal AED for a patient [73]. Common adverse events reported after AED use include dizziness, somnolence, fatigue, headache and gastrointestinal disturbances [27, 73, 74]. Long-term use of some AEDs (most notably, but not exclusively, enzyme inducers) has been associated with reduced bone mineral density and osteoporosis [75, 76]. Therefore, osteodensitometry and other tests of bone metabolism, as well as dietary and lifestyle advice to minimize the risk of osteoporosis are recommended with longterm AED use [21, 22]. Table 1 includes a summary of the most common adverse effects (occurring in more than $10 \%$ of patients as listed in the summaries of product characteristics [SmPCs]) and other important adverse events (as listed in the special warnings and precautions for use in the SmPCs). Detailed information can be found in the SmPCs or recent reviews [73, 74].

\section{Comorbidity}

Several central nervous system-related and other diseases, including depression, anxiety, dementia, migraine, heart disease, peptic ulcers and arthritis are more common in epilepsy patients than in the general population [77]. The presence of concomitant disease is an important determinant in 
the choice of AEDs since certain AEDs are contra-indicated or require special precautions in some of these conditions. More information on this topic can be found in the SmPCs; a summary is presented in Table 1 .

\section{Elderly}

Causes for new-onset seizures in people older than 60 years include cerebrovascular diseases, high blood pressure, diabetes and dementia $[78,79]$. Because of the high prevalence of these and other comorbid conditions, polypharmacy and a higher likelihood of dose-related and idiosyncratic adverse effects in the elderly population, selecting the optimal AED for elderly patients is challenging.

Focal-onset seizures with impaired awareness are the most common seizure type in people over 60 years [78]. For this seizure type, the first-choice AEDs for monotherapy in elderly patients are lamotrigine and levetiracetam; gabapentin and lacosamide can be considered as alternatives (but are not reimbursed as monotherapy in Belgium) $[20,21,23,80$, 81]. Of note, carbamazepine has a poor tolerability profile in elderly people [78, 80, 81].

\section{Pregnancy}

AED use during pregnancy is of concern since AEDs can be transferred to the fetus via the placenta, which can result in fetal growth restriction, major congenital malformations (e.g., neural tube defects and cardiac anomalies) and impaired cognitive development in the child [24, 82-86]. These risks should be balanced against those associated with uncontrolled seizures (particularly generalized tonic-clonic seizures) [24].

Among all AEDs, prenatal exposure to valproate is associated with the highest risk of major congenital malformations, delayed early cognitive skills and neurodevelopmental disorders (e.g., autistic spectrum disorder) [24]. Despite previous efforts to better inform women about these risks and discourage valproate use in girls and women, information was not sufficiently reaching patients $[87,88]$. Therefore, the European Commission issued new legally binding measures in 2018 to avoid in utero exposure to valproate [89]. Valproate is now contraindicated in pregnant women unless there is no other effective treatment available. In girls and women of childbearing potential, valproate can only be used if conditions of a new pregnancy prevention program are met [89]. If valproate is the only effective treatment (which is more likely when treating generalized epilepsies), the dose should be kept as low as possible, because malformation rate is dose-dependent. The malformation rate with a daily dose $<650 \mathrm{mg}$ is comparable to that with high doses of carbamazepine or lamotrigine [83].
Lamotrigine and levetiracetam are first-choice treatment options in pregnant women (and women of childbearing potential) because they carry the lowest risk of major congenital malformations and have no known impact on neurobehavioral development (although data for levetiracetam are still limited) [24]. Carbamazepine is recommended as alternative first choice; it shows higher malformation rates than lamotrigine and levetiracetam but no impact on neurodevelopment [24]. Oxcarbazepine could also be considered; malformation rates are low but data on neurobehavioral development are sparse [24].

Importantly, blood drug levels should be monitored because pregnancy can have a major impact on pharmacokinetic properties of AEDs (e.g., altered absorption, increased distribution volume and renal excretion, and induction of hepatic metabolism). Lamotrigine, levetiracetam and oxcarbazepine serum concentrations decline most markedly, and dose adjustments may be necessary during pregnancy and postpartum [24].

\section{Generic substitution}

While generic AEDs are considered bioequivalent with the original brand name products, there are conflicting reports about the effect of switching from brand name to generic or among generic AEDs on seizure control, adverse effects, health care utilization and adherence [90-92]. The Belgian Center for Pharmacotherapeutic Information designates all AEDs as "no switch", indicating that switching between brands and/or generics is not recommended [5]. When a patient is successfully treated with a particular brand of AED, treatment should be continued with that brand. When initiating treatment, the choice between prescribing a generic or brand-name AED should consider the likelihood of a continuous supply of the compound from the same manufacturer. Importantly, supply problems are a reality for several generics in Belgium [93] and may make health care professionals reluctant to prescribe generic AEDs.

\section{Precision medicine/personalized treatment}

In recent years, great progress has been made in identifying genetic causes of epilepsy and understanding the molecular mechanisms underlying its pathophysiology $[51,94]$. This has allowed the identification of potential therapeutic targets and has helped select the most effective treatment for individual patients (personalized treatment or precision medicine). Well-established approaches of precision medicine include a ketogenic diet in patients with GLUT1 deficiency, vitamin B6 in pyridoxine-dependent epilepsy, sodium channel blockers (e.g., carbamazepine) in patients with neonatal-onset epilepsy due to mutations in potassium or sodium channel genes $(K C N Q 2, S C N 2 A$, 
SCN8A), avoiding sodium channel blockers in Dravet syndrome (characterized by loss-of-function mutations in the sodium channel gene $S C N 1 A$ ), and mTOR inhibitors in mTORopathies (e.g., everolimus to treat focal seizures associated with tuberous sclerosis complex) [51, 94]. Importantly, different mutations in the same gene may have opposite effects and require opposite treatment approaches. For instance, sodium channel blockers only work for $K C N Q 2$ loss-of-function, and $S C N 2 A$ and $S C N 8 A$ gain-of-function mutations [51, 95]. It is, therefore, crucial that treatment strategies are defined after expert multidisciplinary review of pathogenic variants. With an increasing number of targets and drugs being identified, the field of precision medicine is rapidly evolving and may contribute substantially to the advancement of epilepsy treatment.

Funding This work was supported by a grant from UCB Pharma SA/ $\mathrm{NV}$, Brussels, Belgium. UCB facilitated the organization of the expert meetings and paid for medical writing services (provided by Natalie Denef, Modis, Wavre, Belgium), but was not involved in the preparation or review of the recommendations.

\section{Compliance with ethical standards}

Conflict of interest $\mathrm{P}$ Boon has received speaker and consultancy grants from UCB, Medtronic and LivaNova and research grants from the same companies through Ghent University Hospital, outside the submitted work. S Ferrao Santos reports receiving a travel grant from UCB for participation in a medical congress, outside the submitted work. AC Jansen reports speaker honoraria and consultancy fees from Novartis and UCB, outside the submitted work. L Lagae reports grants from UCB, Eisai, Novartis, Zogenix and LivaNova, outside the submitted work; in addition, L Lagae has a patent "Fenfluramine in Dravet syndrome" with potential royalties paid through the University of Leuven. B Legros reports travel grants and speaker honoraria from UCB and speaker honoraria from LivaNova, outside the submitted work. S Weckhuysen reports speaker fees from Biocodex, UCB and Zogenix, and consultancy fees from Xenon and Zogenix, outside the submitted work.

Ethical approval This article does not contain any studies with human participants or animals performed by any of the authors.

Informed consent For this type of study formal consent is not required.

Open Access This article is licensed under a Creative Commons Attribution 4.0 International License, which permits use, sharing, adaptation, distribution and reproduction in any medium or format, as long as you give appropriate credit to the original author(s) and the source, provide a link to the Creative Commons licence, and indicate if changes were made. The images or other third party material in this article are included in the article's Creative Commons licence, unless indicated otherwise in a credit line to the material. If material is not included in the article's Creative Commons licence and your intended use is not permitted by statutory regulation or exceeds the permitted use, you will need to obtain permission directly from the copyright holder. To view a copy of this licence, visit http://creativecommons.org/licenses/by/4.0/.

\section{References}

1. GBD 2016 Epilepsy Collaborators (2019) Global, regional, and national burden of epilepsy, 1990-2016: a systematic analysis for the Global Burden of Disease Study 2016. Lancet Neurol 18:357-375. https://doi.org/10.1016/s1474-4422(18)30454-x

2. Finoulst M, Vankrunkelsven P, Boon P (2017) Chirurgie bij medicatieresistente epilepsie: vroeger doorverwijzen. Tijdschr voor Geneeskunde 73:1503-1505. https://doi.org/10.2143/ TVG.73.23.2002482

3. Fisher RS, Acevedo C, Arzimanoglou A, Bogacz A, Cross JH, Elger CE, Engel J Jr, Forsgren L, French JA, Glynn M, Hesdorffer DC, Lee BI, Mathern GW, Moshe SL, Perucca E, Scheffer IE, Tomson T, Watanabe M, Wiebe S (2014) ILAE official report: a practical clinical definition of epilepsy. Epilepsia 55:475-482. https://doi.org/10.1111/epi.12550

4. Fisher RS (2017) The new classification of seizures by the international league against epilepsy 2017. Curr Neurol Neurosci Rep 17:48. https://doi.org/10.1007/s11910-017-0758-6

5. Belgisch Centrum voor Farmacotherapeutische Informatie/Centre Belge d'Information Pharmacothérapeutique (BCFI/CBIP) Gecommentarieerd geneesmiddelenrepertorium. 10.7 Anti-epileptica. https://www.bcfi.be/nl/chapters/11?frag=8706. Accessed 19 June 2020

6. Boon P, Engelborghs S, Hauman H, Jansen A, Lagae L, Legros B, Ossemann M, Sadzot B, Urbain E, van Rijckevorsel K (2008) Recommendations for the treatment of epilepsies in general practice in Belgium. Acta Neurol Belg 108:118-130

7. Boon P, Engelborghs S, Hauman H, Jansen A, Lagae L, Legros B, Ossemann M, Sadzot B, Smets K, Urbain E, van Rijckevorsel K (2012) Recommendations for the treatment of epilepsy in adult patients in general practice in Belgium: an update. Acta Neurol Belg 112:119-131. https://doi.org/10.1007/s13760-012-0070-9

8. European Medicines Agency (2017) Assessment report: Vimpat (International non-proprietary name: lacosamide). Procedure No. EMEA/H/C/000863/II/0065/G. https://www.ema.europa.eu/en/ documents/variation-report/vimpat-h-c-863-ii-0065-g-epar-asses sment-report-variation_en.pdf. Accessed 19 June 2020

9. European Medicines Agency (2016) Assessment report: Vimpat (International non-proprietary name: lacosamide). Procedure No. EMEA/H/C/000863/II/0060/G. https://www.ema.europa.eu/en/ documents/variation-report/vimpat-h-c-863-ii-0060-g-epar-asses sment-report-variation_en.pdf. Accessed 19 June 2020

10. European Medicines Agency Fycompa: Authorisation details. https://www.ema.europa.eu/en/medicines/human/EPAR/fycom pa. Accessed 19 June 2020

11. European Medicines Agency Briviact: Authorisation details. https ://www.ema.europa.eu/en/medicines/human/EPAR/briviact-italy -nubriveo. Accessed 19 June 2020

12. Belgisch Centrum voor Farmacotherapeutische Informatie/Centre Belge d'Information Pharmacothérapeutique (BCFI/CBIP) (2015) Recente informatie juni 2015: vaccin tegen hepatitis A + buiktyfus, domperidon (rectaal), theofylline (vertraagde vrijst.), chloorhexidine (vaginaal), feneturide, protamine. https://www. bcfi.be/nl/gows/368. Accessed 19 June 2020

13. Belgisch Centrum voor Farmacotherapeutische Informatie/Centre Belge d'Information Pharmacothérapeutique (BCFI/CBIP) (2017) Recente informatie juli 2017: alectinib, ramucirumab, aliskiren, zafirlukast, retigabine, promethazine, vaccin difterie-tetanus. https ://www.bcfi.be/nl/gows/2760. Accessed 19 June 2020

14. Glauser T, Ben-Menachem E, Bourgeois B, Cnaan A, Chadwick D, Guerreiro C, Kalviainen R, Mattson R, Perucca E, Tomson $\mathrm{T}$ (2006) ILAE treatment guidelines: evidence-based analysis of antiepileptic drug efficacy and effectiveness as initial monotherapy 
for epileptic seizures and syndromes. Epilepsia 47:1094-1120. https://doi.org/10.1111/j.1528-1167.2006.00585.x

15. French JA, Kanner AM, Bautista J, Abou-Khalil B, Browne T, Harden CL, Theodore WH, Bazil C, Stern J, Schachter SC, Bergen D, Hirtz D, Montouris GD, Nespeca M, Gidal B, Marks WJ Jr, Turk WR, Fischer JH, Bourgeois B, Wilner A, Faught RE Jr, Sachdeo RC, Beydoun A, Glauser TA (2004) Efficacy and tolerability of the new antiepileptic drugs, I: treatment of new-onset epilepsy: report of the TTA and QSS Subcommittees of the American Academy of Neurology and the American Epilepsy Society. Epilepsia 45:401-409. https://doi.org/10.1111/j.0013-9580.2004.06204.x

16. French JA, Kanner AM, Bautista J, Abou-Khalil B, Browne T, Harden CL, Theodore WH, Bazil C, Stern J, Schachter SC, Bergen D, Hirtz D, Montouris GD, Nespeca M, Gidal B, Marks WJ Jr, Turk WR, Fischer JH, Bourgeois B, Wilner A, Faught RE Jr, Sachdeo RC, Beydoun A, Glauser TA (2004) Efficacy and tolerability of the new antiepileptic drugs, II: treatment of refractory epilepsy: report of the TTA and QSS Subcommittees of the American Academy of Neurology and the American Epilepsy Society. Epilepsia 45:410-423. https://doi.org/10.1111/j.0013-9580.2004.06304.x

17. Scottish Intercollegiate Guidelines Network (2003) SIGN 70: Diagnosis and management of epilepsy in adults. https://www. sign.ac.uk/archived-guidelines.html. Accessed 7 April 2020

18. National Institute for Health and Care Excellence (Oct 2004) The epilepsies: The diagnosis and management of the epilepsies in adults and children in primary and secondary care: Clinical guideline [CG20]. https://www.nice.org.uk/guidance/cg20. Accessed 7 April 2020

19. Kanner AM, Ashman E, Gloss D, Harden C, Bourgeois B, Bautista JF, Abou-Khalil B, Burakgazi-Dalkilic E, Llanas Park E, Stern J, Hirtz D, Nespeca M, Gidal B, Faught E, French J (2018) Practice guideline update summary: efficacy and tolerability of the new antiepileptic drugs II: treatment-resistant epilepsy: Report of the Guideline Development, Dissemination, and Implementation Subcommittee of the American Academy of Neurology and the American Epilepsy Society. Neurology 91:82-90. https://doi. org/10.1212/wnl.0000000000005756

20. Kanner AM, Ashman E, Gloss D, Harden C, Bourgeois B, Bautista JF, Abou-Khalil B, Burakgazi-Dalkilic E, Llanas Park E, Stern J, Hirtz D, Nespeca M, Gidal B, Faught E, French J (2018) Practice guideline update summary: efficacy and tolerability of the new antiepileptic drugs I: treatment of new-onset epilepsy: report of the Guideline Development, Dissemination, and Implementation Subcommittee of the American Academy of Neurology and the American Epilepsy Society. Neurology 91:74-81. https://doi. org/10.1212/wnl.0000000000005755

21. Scottish Intercollegiate Guidelines Network (2015, revised 2018) SIGN 143: Diagnosis and management of epilepsy in adults. https ://www.sign.ac.uk/assets/sign143_2018.pdf. Accessed 7 April 2020

22. National Institute for Health and Care Excellence (2012) (last updated February 2020) Epilepsies: diagnosis and management: Clinical guideline [CG137]. https://www.nice.org.uk/guidance/ cg137/chapter/1-Guidance. Accessed 7 April 2020

23. Glauser T, Ben-Menachem E, Bourgeois B, Cnaan A, Guerreiro C, Kalviainen R, Mattson R, French JA, Perucca E, Tomson T (2013) Updated ILAE evidence review of antiepileptic drug efficacy and effectiveness as initial monotherapy for epileptic seizures and syndromes. Epilepsia 54:551-563. https://doi.org/10.1111/epi.12074

24. Tomson T, Battino D, Bromley R, Kochen S, Meador K, Pennell P, Thomas SV (2019) Management of epilepsy in pregnancy: a report from the International League Against Epilepsy Task Force on Women and Pregnancy. Epileptic Disord 21:497-517. https:// doi.org/10.1684/epd.2019.1105
25. RIZIV/INAMI Vergoedbare geneesmiddelen/Médicaments remboursables. https://ondpanon.riziv.fgov.be/SSPWebApplicati onPublic/nl/Public/ProductSearch. Accessed 7 April 2020

26. Campos MSdA, Ayres LR, Morelo MRS, Marques FA, Pereira LRL (2016) Efficacy and tolerability of antiepileptic drugs in patients with focal epilepsy: systematic review and network meta-analyses. Pharmacotherapy 36:1255-1271. https://doi. org/10.1002/phar.1855

27. Nevitt SJ, Sudell M, Weston J, Tudur Smith C, Marson AG (2017) Antiepileptic drug monotherapy for epilepsy: a network metaanalysis of individual participant data. Cochrane Database Syst Rev 12:CD011412. https://doi.org/10.1002/14651858.CD011412. pub3

28. Brodie MJ, Barry SJ, Bamagous GA, Norrie JD, Kwan P (2012) Patterns of treatment response in newly diagnosed epilepsy. Neurology 78:1548-1554. https://doi.org/10.1212/WNL.0b013e3182 $563 \mathrm{~b} 19$

29. Rosati A, Ilvento L, Lucenteforte E, Pugi A, Crescioli G, McGreevy KS, Virgili G, Mugelli A, De Masi S, Guerrini R (2018) Comparative efficacy of antiepileptic drugs in children and adolescents: a network meta-analysis. Epilepsia 59:297-314. https://doi.org/10.1111/epi.13981

30. Perucca E, Brodie MJ, Kwan P, Tomson T (2020) 30 years of second-generation antiseizure medications: impact and future perspectives. Lancet Neurol 19:544-556. https://doi.org/10.1016/ s1474-4422(20)30035-1

31. Campos MSdA, Ayres LR, Morelo MRS, Carizio FAM, Pereira LRL (2018) Comparative efficacy of antiepileptic drugs for patients with generalized epileptic seizures: systematic review and network meta-analyses. Int J Clin Pharm 40:589-598. https ://doi.org/10.1007/s11096-018-0641-9

32. Shorvon SD, Bermejo PE, Gibbs AA, Huberfeld G, Kalviainen R (2018) Antiepileptic drug treatment of generalized tonic-clonic seizures: an evaluation of regulatory data and five criteria for drug selection. Epilepsy Behav 82:91-103. https://doi.org/10.1016/j. yebeh.2018.01.039

33. Brigo F, Igwe SC, Lattanzi S (2019) Ethosuximide, sodium valproate or lamotrigine for absence seizures in children and adolescents. Cochrane Database Syst Rev 2:CD003032. https://doi. org/10.1002/14651858.CD003032.pub4

34. Striano P, Belcastro V (2017) Update on pharmacotherapy of myoclonic seizures. Expert Opin Pharmacother 18:187-193. https:// doi.org/10.1080/14656566.2017.1280459

35. Park KM, Kim SE, Lee BI (2019) Antiepileptic drug therapy in patients with drug-resistant epilepsy. J Epilepsy Res 9:14-26. https://doi.org/10.14581/jer.19002

36. Brodie MJ (2010) Antiepileptic drug therapy the story so far. Seizure 19:650-655. https://doi.org/10.1016/j.seizure.2010.10.027

37. Rho JM, White HS (2018) Brief history of anti-seizure drug development. Epilepsia Open 3:114-119. https://doi.org/10.1002/ epi4.12268

38. Verrotti A, Lattanzi S, Brigo F, Zaccara G (2020) Pharmacodynamic interactions of antiepileptic drugs: from bench to clinical practice. Epilepsy Behav 104:106939. https://doi.org/10.1016/j. yebeh.2020.106939

39. Brigo F, Bragazzi NL, Nardone R, Trinka E (2016) Efficacy and tolerability of brivaracetam compared to lacosamide, eslicarbazepine acetate, and perampanel as adjunctive treatments in uncontrolled focal epilepsy: Results of an indirect comparison metaanalysis of RCTs. Seizure 42:29-37. https://doi.org/10.1016/j. seizure.2016.08.007

40. Hu Q, Zhang F, Teng W, Hao F, Zhang J, Yin M, Wang N (2018) Efficacy and safety of antiepileptic drugs for refractory partialonset epilepsy: a network meta-analysis. J Neurol 265:1-11. https ://doi.org/10.1007/s00415-017-8621-x 
41. Li-Na Z, Deng C, Hai-Jiao W, Da X, Ge T, Ling L (2018) Indirect comparison of third-generation antiepileptic drugs as adjunctive treatment for uncontrolled focal epilepsy. Epilepsy Res 139:6072. https://doi.org/10.1016/j.eplepsyres.2017.11.008

42. Zhu LN, Chen D, Xu D, Tan G, Wang HJ, Liu L (2017) Newer antiepileptic drugs compared to levetiracetam as adjunctive treatments for uncontrolled focal epilepsy: an indirect comparison. Seizure 51:121-132. https://doi.org/10.1016/j.seizure.2017.07.017

43. Wheless JW, Clarke DF, Arzimanoglou A, Carpenter D (2007) Treatment of pediatric epilepsy: European expert opinion, 2007. Epileptic Disord 9:353-412. https://doi.org/10.1684/ epd.2007.0144

44. Wilmshurst JM, Gaillard WD, Vinayan KP, Tsuchida TN, Plouin P, Van Bogaert P, Carrizosa J, Elia M, Craiu D, Jovic NJ, Nordli D, Hirtz D, Wong V, Glauser T, Mizrahi EM, Cross JH (2015) Summary of recommendations for the management of infantile seizures: Task Force Report for the ILAE Commission of Pediatrics. Epilepsia 56:1185-1197. https://doi.org/10.1111/epi.13057

45. Glauser TA, Cnaan A, Shinnar S, Hirtz DG, Dlugos D, Masur D, Clark PO, Capparelli EV, Adamson PC (2010) Ethosuximide, valproic acid, and lamotrigine in childhood absence epilepsy. N Engl J Med 362:790-799. https://doi.org/10.1056/NEJMoa0902 014

46. Samanta D, Al Khalili Y (2020) Electrical status epilepticus in sleep (ESES). In: StatPearls. StatPearls Publishing Copyright () 2020, StatPearls Publishing LLC., Treasure Island (FL)

47. O'Callaghan FJ, Edwards SW, Alber FD, Hancock E, Johnson AL, Kennedy CR, Likeman M, Lux AL, Mackay M, Mallick AA, Newton RW, Nolan M, Pressler R, Rating D, Schmitt B, Verity CM, Osborne JP (2017) Safety and effectiveness of hormonal treatment versus hormonal treatment with vigabatrin for infantile spasms (ICISS): a randomised, multicentre, open-label trial. Lancet Neurol 16:33-42. https://doi.org/10.1016/s1474 $-4422(16) 30294-0$

48. O'Callaghan FJK, Edwards SW, Alber FD, Cortina Borja M, Hancock E, Johnson AL, Kennedy CR, Likeman M, Lux AL, Mackay MT, Mallick AA, Newton RW, Nolan M, Pressler R, Rating D, Schmitt B, Verity CM, Osborne JP (2018) Vigabatrin with hormonal treatment versus hormonal treatment alone (ICISS) for infantile spasms: 18-month outcomes of an open-label, randomised controlled trial. Lancet Child Adolesc Health 2:715-725. https:// doi.org/10.1016/s2352-4642(18)30244-x

49. Cross JH, Caraballo RH, Nabbout R, Vigevano F, Guerrini R, Lagae L (2019) Dravet syndrome: treatment options and management of prolonged seizures. Epilepsia 60(Suppl 3):S39-s48. https ://doi.org/10.1111/epi.16334

50. Cross JH, Auvin S, Falip M, Striano P, Arzimanoglou A (2017) Expert opinion on the management of Lennox-Gastaut syndrome: treatment algorithms and practical considerations. Front Neurol 8:505. https://doi.org/10.3389/fneur.2017.00505

51. Perucca P, Perucca E (2019) Identifying mutations in epilepsy genes: Impact on treatment selection. Epilepsy Res 152:18-30. https://doi.org/10.1016/j.eplepsyres.2019.03.001

52. Pisano T, Numis AL, Heavin SB, Weckhuysen S, Angriman M, Suls A, Podesta B, Thibert RL, Shapiro KA, Guerrini R, Scheffer IE, Marini C, Cilio MR (2015) Early and effective treatment of KCNQ2 encephalopathy. Epilepsia 56:685-691. https://doi. org/10.1111/epi.12984

53. Thijs RD, Surges R, O'Brien TJ, Sander JW (2019) Epilepsy in adults. Lancet 393:689-701. https://doi.org/10.1016/s0140 -6736(18)32596-0

54. Kwan P, Brodie MJ (2000) Early identification of refractory epilepsy. N Engl J Med 342:314-319. https://doi.org/10.1056/nejm2 00002033420503

55. Tellez-Zenteno JF, Hernandez-Ronquillo L, Buckley S, Zahagun R, Rizvi S (2014) A validation of the new definition of drug-resistant epilepsy by the International League Against Epilepsy. Epilepsia 55:829-834. https://doi.org/10.1111/epi.12633

56. Kwan P, Arzimanoglou A, Berg AT, Brodie MJ, Allen Hauser W, Mathern G, Moshe SL, Perucca E, Wiebe S, French J (2010) Definition of drug resistant epilepsy: consensus proposal by the ad hoc Task Force of the ILAE Commission on Therapeutic Strategies. Epilepsia 51:1069-1077. https://doi.org/10.111 $1 /$ j.1528-1167.2009.02397.x

57. Dalic L, Cook MJ (2016) Managing drug-resistant epilepsy: challenges and solutions. Neuropsychiatr Dis Treat 12:2605-2616. https://doi.org/10.2147/ndt.s84852

58. Engel J Jr (2016) What can we do for people with drug-resistant epilepsy? The 2016 Wartenberg Lecture. Neurology 87:24832489. https://doi.org/10.1212/wnl.0000000000003407

59. Bjellvi J, Olsson I, Malmgren K, Wilbe Ramsay K (2019) Epilepsy duration and seizure outcome in epilepsy surgery: a systematic review and meta-analysis. Neurology 93:e159-e166. https:// doi.org/10.1212/wnl.0000000000007753

60. Boon P, De Cock E, Mertens A, Trinka E (2018) Neurostimulation for drug-resistant epilepsy: a systematic review of clinical evidence for efficacy, safety, contraindications and predictors for response. Curr Opin Neurol 31:198-210. https://doi.org/10.1097/ wco.0000000000000534

61. Sondhi V, Sharma S (2020) Non-pharmacological and non-surgical treatment of refractory childhood epilepsy. Indian J Pediatr. https://doi.org/10.1007/s12098-019-03164-3

62. Bouwens van der Vlis TAM, Schijns OEMG, Schaper FLWVJ, Hoogland G, Kubben P, Wagner L, Rouhl R, Temel Y, Ackermans L (2019) Deep brain stimulation of the anterior nucleus of the thalamus for drug-resistant epilepsy. Neurosurg Rev 42:287-296. https://doi.org/10.1007/s10143-017-0941-x

63. Armeno M, Caraballo R (2020) The evolving indications of KD therapy. Epilepsy Res 163:106340. https://doi.org/10.1016/j.eplep syres.2020.106340

64. Westbrook C, Subramaniam T, Seagren RM, Tarula E, Co D, Furstenberg-Knauff M, Wallace A, Hsu D, Payne E (2019) Febrile infection-related epilepsy syndrome treated successfully with anakinra in a 21-year-old woman. WMJ 118:135-139

65. Kenney-Jung DL, Vezzani A, Kahoud RJ, LaFrance-Corey RG, Ho ML, Muskardin TW, Wirrell EC, Howe CL, Payne ET (2016) Febrile infection-related epilepsy syndrome treated with anakinra. Ann Neurol 80:939-945. https://doi.org/10.1002/ana.24806

66. Payne ET, Koh S, Wirrell EC (2020) Extinguishing febrile infection-related epilepsy syndrome: pipe dream or reality? Semin Neurol 40:263-272. https://doi.org/10.1055/s-0040-1708503

67. Elliott J, DeJean D, Clifford T, Coyle D, Potter BK, Skidmore B, Alexander C, Repetski AE, Shukla V, McCoy B, Wells GA (2019) Cannabis-based products for pediatric epilepsy: a systematic review. Epilepsia 60:6-19. https://doi.org/10.1111/epi.14608

68. Federaal Agentschap voor Geneesmiddelen en Gezondheidsproducten/Agence Fédérale des Médicaments et des Produits de Santé (2019) Omzendbrief nr. 648: Interpretatie van het koninklijk besluit van 11 juni 2015 tot het reglementeren van producten die één of meer tetrahydrocannabinolen bevatten, voor wat betreft grondstoffen voor magistrale bereidingen. https://www.vbb.com/ media/Insights_Newsletters/omzendbrief_648_nl_thc_for_web. pdf. Accessed 7 April 2020

69. European Medicines Agency (2019) Epidyolex: Summary of product characteristics. https://www.ema.europa.eu/en/documents/ product-information/epidyolex-epar-product-information_en.pdf. Accessed 7 April 2020

70. Marvanova M (2016) Pharmacokinetic characteristics of antiepileptic drugs (AEDs). Ment Health Clin 6:8-20. https://doi. org/10.9740/mhc.2015.01.008

71. Patsalos PN (2013) Drug interactions with the newer antiepileptic drugs (AEDs) - part 1: pharmacokinetic and pharmacodynamic 
interactions between AEDs. Clin Pharmacokinet 52:927-966. https://doi.org/10.1007/s40262-013-0087-0

72. Patsalos PN (2013) Drug interactions with the newer antiepileptic drugs (AEDs) - part 2: pharmacokinetic and pharmacodynamic interactions between AEDs and drugs used to treat non-epilepsy disorders. Clin Pharmacokinet 52:1045-1061. https://doi. org/10.1007/s40262-013-0088-z

73. Brodie MJ (2017) Tolerability and safety of commonly used antiepileptic drugs in adolescents and adults: a clinician's overview. CNS Drugs 31:135-147. https://doi.org/10.1007/s4026 3-016-0406-8

74. Moavero R, Pisani LR, Pisani F, Curatolo P (2018) Safety and tolerability profile of new antiepileptic drug treatment in children with epilepsy. Expert Opin Drug Saf 17:1015-1028. https://doi. org/10.1080/14740338.2018.1518427

75. Miziak B, Błaszczyk B, Chrościńska-Krawczyk M, Danilkiewicz G, Jagiełło-Wójtowicz E, Czuczwar SJ (2014) The problem of osteoporosis in epileptic patients taking antiepileptic drugs. Expert Opin Drug Saf 13:935-946. https://doi.org/10.1517/14740 338.2014.919255

76. Miziak B, Chrościńska-Krawczyk M, Czuczwar SJ (2019) An update on the problem of osteoporosis in people with epilepsy taking antiepileptic drugs. Expert Opin Drug Saf 18:679-689. https://doi.org/10.1080/14740338.2019.1625887

77. Keezer MR, Sisodiya SM, Sander JW (2016) Comorbidities of epilepsy: current concepts and future perspectives. Lancet Neurol 15:106-115. https://doi.org/10.1016/s1474-4422(15)00225-2

78. Vu LC, Piccenna L, Kwan P, O’Brien TJ (2018) New-onset epilepsy in the elderly. Br J Clin Pharmacol 84:2208-2217. https:// doi.org/10.1111/bcp. 13653

79. Brodie MJ, Elder AT, Kwan P (2009) Epilepsy in later life. Lancet Neurol 8:1019-1030. https://doi.org/10.1016/s1474 -4422(09)70240-6

80. Lattanzi S, Trinka E, Del Giovane C, Nardone R, Silvestrini M, Brigo F (2019) Antiepileptic drug monotherapy for epilepsy in the elderly: a systematic review and network meta-analysis. Epilepsia. https://doi.org/10.1111/epi.16366

81. Lezaic N, Gore G, Josephson CB, Wiebe S, Jette N, Keezer MR (2019) The medical treatment of epilepsy in the elderly: a systematic review and meta-analysis. Epilepsia 60:1325-1340. https:// doi.org/10.1111/epi.16068

82. Bromley RL, Weston J, Marson AG (2017) Maternal use of antiepileptic agents during pregnancy and major congenital malformations in children. JAMA 318:1700-1701. https://doi.org/10.1001/ jama.2017.14485

83. Tomson T, Battino D, Bonizzoni E, Craig J, Lindhout D, Perucca E, Sabers A, Thomas SV, Vajda F (2018) Comparative risk of major congenital malformations with eight different antiepileptic drugs: a prospective cohort study of the EURAP registry. Lancet Neurol 17:530-538. https://doi.org/10.1016/s1474 $-4422(18) 30107-8$

84. Vajda FJE, Graham JE, Hitchcock AA, Lander CM, O'Brien TJ, Eadie MJ (2019) Antiepileptic drugs and foetal malformation: analysis of 20 years of data in a pregnancy register. Seizure 65:611. https://doi.org/10.1016/j.seizure.2018.12.006

85. Veroniki AA, Cogo E, Rios P, Straus SE, Finkelstein Y, Kealey R, Reynen E, Soobiah C, Thavorn K, Hutton B, Hemmelgarn BR,
Yazdi F, D’Souza J, MacDonald H, Tricco AC (2017) Comparative safety of anti-epileptic drugs during pregnancy: a systematic review and network meta-analysis of congenital malformations and prenatal outcomes. BMC Med 15:95. https://doi.org/10.1186/ s12916-017-0845-1

86. Weston J, Bromley R, Jackson CF, Adab N, Clayton-Smith J, Greenhalgh J, Hounsome J, McKay AJ, Tudur Smith C, Marson AG (2016) Monotherapy treatment of epilepsy in pregnancy: congenital malformation outcomes in the child. Cochrane Database Syst Rev 11:CD010224. https://doi.org/10.1002/14651858.CD010 224.pub2

87. European Medicines Agency (2017) Summary of the EMA public hearing on valproate in pregnancy. https://www.ema.europa.eu/en/ documents/other/summary-ema-public-hearing-valproate-pregn ancy_en.pdf. Accessed 7 April 2020

88. Wise $\mathbf{J}$ (2017) Women still not being told about pregnancy risks of valproate. BMJ 358:j4426. https://doi.org/10.1136/bmj.j4426

89. European Medicines Agency (2018) New measures to avoid valproate exposure in pregnancy endorsed. https://www.ema.europ a.eu/en/documents/referral/valproate-article-31-referral-newmeasures-avoid-valproate-exposure-pregnancy-endorsed_en-0. pdf. Accessed 7 April 2020

90. Holtkamp M, Theodore WH (2018) Generic antiepileptic drugssafe or harmful in patients with epilepsy? Epilepsia 59:12731281. https://doi.org/10.1111/epi.14439

91. Kwan P, Palmini A (2017) Association between switching antiepileptic drug products and healthcare utilization: a systematic review. Epilepsy Behav 73:166-172. https://doi.org/10.1016/j. yebeh.2017.05.010

92. Talati R, Scholle JM, Phung OP, Baker EL, Baker WL, Ashaye A, Kluger J, Coleman CI, White CM (2012) Efficacy and safety of innovator versus generic drugs in patients with epilepsy: a systematic review. Pharmacotherapy 32:314-322. https://doi.org/10 .1002/j.1875-9114.2012.01099.x

93. Federaal Agentschap voor Geneesmiddelen en Gezondheidsproducten/Agence Fédérale des Médicaments et des Produits de Santé Medicinal Product Database: Search human medicinal product with supply problem. https://geneesmiddelendatabank.fagg-afmps .be/\#/query/supply-problem/human. Accessed 7 April 2020

94. Reif PS, Tsai MH, Helbig I, Rosenow F, Klein KM (2017) Precision medicine in genetic epilepsies: break of dawn? Expert Rev Neurother 17:381-392. https://doi.org/10.1080/14737 175.2017.1253476

95. Sanders SJ, Campbell AJ, Cottrell JR, Moller RS, Wagner FF, Auldridge AL, Bernier RA, Catterall WA, Chung WK, Empfield JR, George AL Jr, Hipp JF, Khwaja O, Kiskinis E, Lal D, Malhotra D, Millichap JJ, Otis TS, Petrou S, Pitt G, Schust LF, Taylor CM, Tjernagel J, Spiro JE, Bender KJ (2018) Progress in understanding and treating SCN2A-mediated disorders. Trends Neurosci 41:442-456. https://doi.org/10.1016/j.tins.2018.03.011

Publisher's Note Springer Nature remains neutral with regard to jurisdictional claims in published maps and institutional affiliations. 


\section{Affiliations}

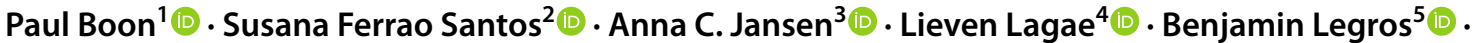 Sarah Weckhuysen ${ }^{6,7}[$}

1 Reference Center for Refractory Epilepsy, Department of Neurology, Ghent University Hospital, Ghent, Belgium

2 Refractory Epilepsy Center, Saint-Luc University Hospital, Brussels, Belgium

3 Pediatric Neurology Unit, Department of Pediatrics, UZ Brussel, Vrije Universiteit Brussel, Brussels, Belgium

4 Reference Center for Refractory Epilepsy, Pediatric Neurology, Department of Development and Regeneration, University Hospitals Leuven, Leuven, Belgium
5 Department of Neurology, Reference Center for the Treatment of Refractory Epilepsy, Hôpital Erasme, Université Libre de Bruxelles (ULB), Brussels, Belgium

6 Department of Neurology, Antwerp University Hospital, Antwerp, Belgium

7 VIB-Center for Molecular Neurology, University of Antwerp, Antwerp, Belgium 